\title{
Note on the paleobiogeography of Compsognathidae (Dinosauria: Theropoda) and its paleoecological implications
}

\author{
MARCOS A.F. SALES ${ }^{1}$, PAULO CASCON ${ }^{2}$ and CESAR L. SCHULTZ ${ }^{3}$ \\ ${ }^{1}$ Programa de Pós-Graduação em Geociências, Departamento de Paleontologia e Estratigrafia, Instituto de Geociências, \\ Universidade Federal do Rio Grande do Sul, Av. Bento Gonçalves, 9500, Agronomia, 91501-970 Porto Alegre, RS, Brasil \\ ${ }^{2}$ Departamento de Biologia, Universidade Federal do Ceará, Av. Mister Hull, Pici, 60455-760 Fortaleza, CE, Brasil \\ ${ }^{3}$ Departamento de Paleontologia e Estratigrafia, Instituto de Geociências, Universidade Federal do Rio Grande do Sul, \\ Av. Bento Gonçalves, 9500, Agronomia, 91501-970 Porto Alegre, RS, Brasil
}

Manuscript received on april 16, 2012; accepted for publication on June 4, 2013

\begin{abstract}
The paleobiogeography of the theropod clade Compsognathidae is here reaccessed in order to test the hypothesis of this taxon being adapted specifically to inhabit semi-arid environments. Data about localities where these fossils were collected and their paleoenvironments were gathered from the literature. Compsognathids seem to be found especially in sedimentary deposits known as Fossil Lagerstätten, which were formed under a set of specific conditions that allowed the preservation of the fragile bone remains of these animals. This bias limits an accurate analysis of the historical and/or ecological paleobiogeography of this taxon. Actually, it is possible that compsognathids had an almost worldwide distribution during the Mesozoic Era. Their occurrence in Lower Cretaceous rocks of China suggests that they also inhabited environments with moist conditions instead of being restricted to semi-arid to arid environments.
\end{abstract}

Key words: Compsognathidae, Fossil Lagerstätten, fossil record, paleobiogeography, paleoecology, Theropoda.

\section{INTRODUCTION}

Compsognathidae is a group of small theropods that has been positioned among basal coelurosaurs in recent phylogenies (Holtz Jr 1998, Sereno 1999, Senter 2007). In recent years, compsognathids have taken an important role in discussions about the origin of feathers and their color patterns (Xu 2006, Zhang et al. 2006, 2010). However, few considerations on their paleoecology and paleobiogeography were made so far. One attempt is from Naish et al. (2004), who considered these theropods as "specifically adapted to inhabit semi-

Correspondence to: Marcos André Fontenele Sales

E-mail:marcos.paleo@yahoo.com.br arid environments" once they were found in the Solnhofen Plattenkalk and Santana Formation.

When Naish et al. (2004) proposed this scenario they recognized only four species as members of Compsognathidae: which were the Laurasian Compsognathus longipes, Aristosuchus pusillus, and Sinosauropteryx prima and the Gondwanan Mirischia asymmetrica. Therefore, it is necessary to review the distribution of this taxon and its paleoecological implications given that four other species described after Naish et al. (2004) are now also considered as compsognathids (Peyer 2006, Ji et al. 2007, dal Sasso and Maganuco 2011) and that they did not take into account the paleoenvironment 
of the Early Cretaceous Jehol Biota, where S. prima inhabited. Hence the aim of this work is to reanalyze the paleobiogeography of Compsognathidae sensu Peyer (2006) and its implications, especially if it can (or cannot) support the paleoecological inference aforementioned. In order to do this, data about localities where compsognathids were found and the paleoenvironments where they inhabited were compiled and reviewed.

\section{COMPSOGNATHIDS THROUGH SPACE AND TIME}

Compsognathidae comprise a set of species with unclear relationships among them and with other theropods, so sometimes it appears as a nonmonophyletic group. Testing the monophyly of this taxon will require further phylogenetic studies, including especially more basal coelurosaurs(Chiappe and Göhlich 2010). In order to define the range of taxa that is considered here to be a compsognathid, the diagnostic features proposed by Peyer (2006) are adopted: (i) fan-shaped mid to posterior dorsal neural spines; (ii) metacarpal I very stout, approximately as broad as long; (iii) proximal width of phalanx I-1 more than minimal shaft diameter of radius; (iv) lack of an external mandibular fenestra; (v) lack of pleurocoels in dorsal vertebrae; (vi) short, wide and only slightly inclined dorsal transverse processes; (vii) hook-shaped ligament attachments on dorsal neural spines. This combination of features is not the same as those employed by other authors (eg. Chen et al. 1998, Hwang et al. 2004, Naish et al. 2004, Göhlich and Chiappe 2006), but circumscribe all the species assigned by them to Compsognathidae. These species are presented below in temporal order.

The first compsognathid described was Compsognathus longipes Wagner 1861, firstly found in Solnhofen Litographic Limestones, also known as the Solnhofen Plattenkalk, in Germany (Ostrom 1978). More recently it was also recovered from Canjuers limestones in France (Peyer 2006) and, possibly, in Portugal (Antunes and Mateus 2003, Mateus et al. 2006). All these records are Late
Jurassic in age (Fig. 1a). Juravenator starki Göhlich and Chiappe 2006 is also from Germany, but it was found in the Schamhaupten plattenkalk, which is at least five million years older than Solnhofen (Göhlich and Chiappe 2006, Chiappe and Göhlich 2010). In this way the two species were not coeval. However, there is some disagreement concerning the compsognathid identity of $J$. starki (Xu 2006, Butler and Upchurch 2007).

The Early Cretaceous compsognathid fossil record includes taxa recovered from Europe, Asia and South America (Fig. 1b). Scipionyx samniticus dal Sasso and Signore 1998, from the Pietraroia Plattenkalk, in Italy, and Aristosuchus pusillus Owen 1876, from the Wessex Formation, in Great Britain, are the European species (Seeley 1887, dal Sasso and Signore 1998). Their allocation in Compsognathidae is sustained by some authors (Naish 2002, Naish et al. 2004, Peyer 2006, Naish and Martill 2007, dal Sasso and Maganuco 2011).

All the Asiatic compsognathid species come from the Yixian Formation, in China. Despite some disputes, an Early Cretaceous age is usually assumed for this stratigraphic unit (Zhou et al. 2003, Tan and Ren 2006, Liu et al. 2012). The first Chinese taxon described was Sinosauropteryx prima Ji and Ji 1996 (Chen et al. 1998) and the second Huaxiagnathus orientalis Hwang et al. 2004 (Hwang et al. 2004). The third species, named Sinocalliopteryx gigas Ji et al. 2007 (Ji et al. 2007), was described after the work of Peyer (2006).

Lastly, Mirischia asymmetrica Naish et al. 2004, from the Santana Formation (Early Cretaceous, Brazil; Naish et al. 2004), is the only compsognathid discovered hitherto in Gondwana (Naish et al. 2004, Bittencourt and Langer 2011, but see dal Sasso and Maganuco 2011).

\section{DISCUSSION}

The presence of an organism is promptly confirmed when body fossils or ichnofossils securely assigned to it are found in a determined area. However, the 

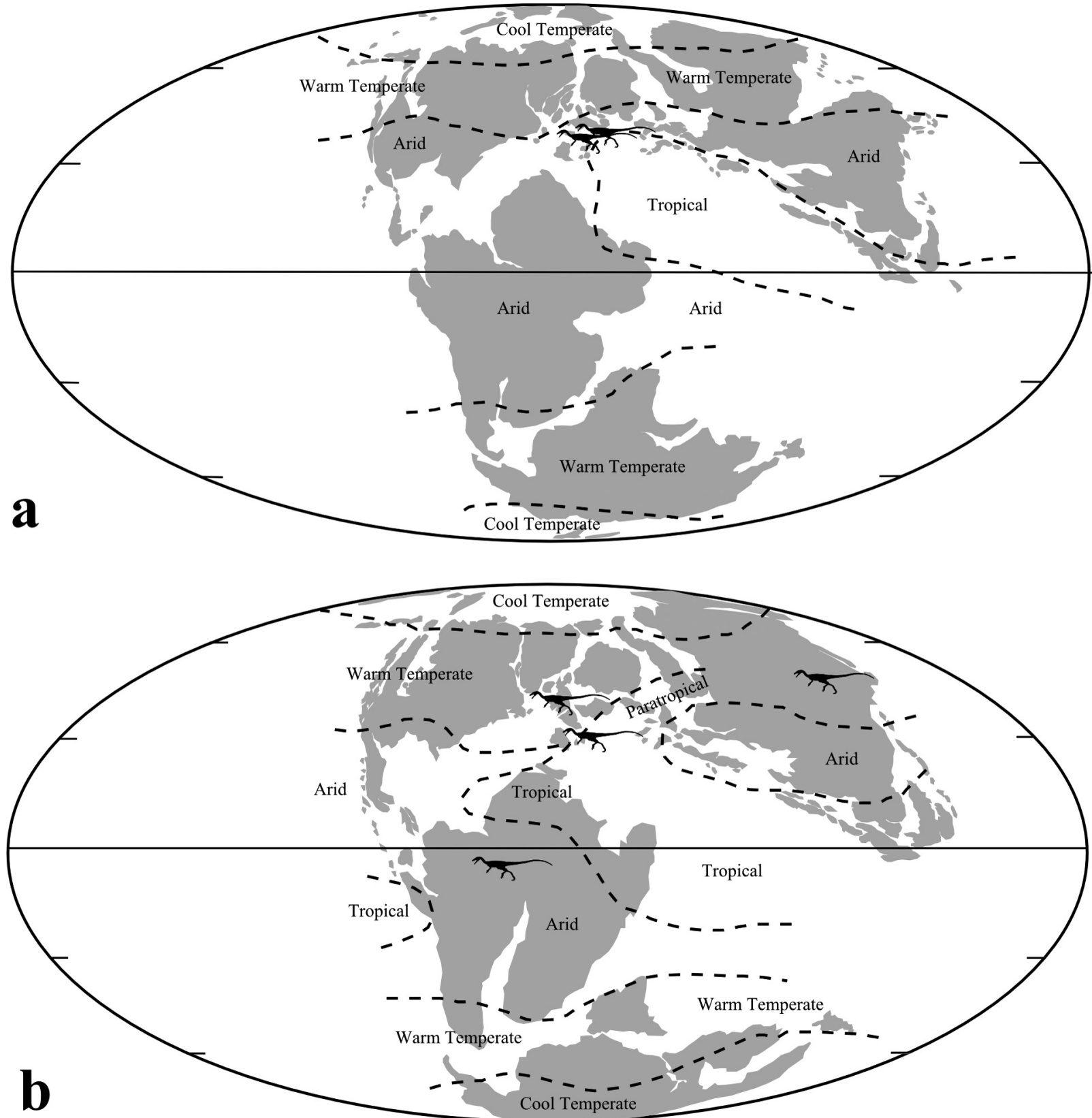

Fig. 1 - Paleogeographic maps of (a) Late Jurassic and (b) Early Cretaceous times showing the geographical distribution of compsognathids. The areas of occurrence are signalized with compsognathid body icons. Because of the proximity, the occurences within the same country were indicated with only one body icon. Body icons were modified from Naish et al. (2004), while the maps from Blakey (2006) are after Scotese (2002).

absence of an organism is more difficult to prove as it might be due to three main reasons (Upchurch et al. 2002): (i) it never inhabited that area; (ii) it inhabited there but then became extinct; and (iii) it inhabited that region but its fossils have not been preserved or discovered yet.
Before analyzing the paleobiogeographic distribution of Compsognathidae, it is fundamental to highlight that most of the species came from Fossil Lagerstätten, sedimentary deposits with exquisite fossil records. Solnhofen and Santana Formations have been known because of their 
exceptional fossils, which are listed in compendia dedicated exclusively to each sedimentary deposit (eg. Maisey 1991, Frickhinger 1994). In fact, Martill (1990) considered these two deposits among the ten principal Fossil Lagerstätten of the world. The Yixian Formation, along with other formations of the Jehol Group, has contributed with many excellently preserved fossils to the discussions about the origin and/or radiation of important taxa, like angiosperms and mammals (Lucas 2001, Zhou et al. 2003, Zhou 2006, Liu et al. 2012). The Pietroroia Plattenkalk and Schamhaupten Plattenkalk also have well-preserved fossil specimens and can be considered among the main Fossil Lagerstätten (dal Sasso and Signore 1998, dal Sasso 2003, Chiappe and Göhlich 2010).

This could mean that these small-bodied animals, with skeletons constituted by relatively fragile elements, would require some special conditions for their preservation as fossils. Indeed, most specimens are in excellent state of preservation and some of them also have soft tissues, feathers and/or gut contents preserved (Ostrom 1978, Norman 1990, Chen et al. 1998, dal Sasso and Signore 1998, Naish et al. 2004, Göhlich and Chiappe 2006, Ji et al. 2007, Chiappe and Göhlich 2010). If this hypothesis is correct two implications are plausible (see below).

The first one is that the distribution of this taxon during Mesozoic times could have been larger than that suggested by the fossil record. In fact, compsognathids were small carnivores whose diet included small vertebrates (Ostrom 1978, Norman 1990, Chen et al. 1998, Ji et al. 2007). Actually this trophic niche should have been present in almost all types of ecosystems during Late Jurassic and Early Cretaceous, from forests to deserts (Zhou 2006, Leonardi et al. 2007). So it seems that there were no major trophic restrictions to the presence of compsognathids in other areas of the world, although possible competition with other theropods and terrestrial taxa should be also taken into account when speculating that.
The second aspect concerns the absence of this clade in Africa. Once this group was found in Europe, Asia and South America, it would be expected that it was also present in the African continent, the main land connection between Laurasia and South America until the end of the Early Cretaceous (Naish et al. 2004, Sereno et al. 2004). Russell and Paesler (2003) commented that the taphonomy of Early Cretaceous African fluvial deposits favored the preservation of robust bony elements, so that the presence of small and delicate taxa would be negatively biased. Accordingly, it is also likely that the diversity of small dinosaurs has not been well sampled (Russell and Paesler 2003). Therefore, it is plausible that the unfavorable fossilization conditions prevented the fossil record of Compsognathidae in Africa, what does not exclude the possibility that these theropods may be found there in the future (Upchurch et al. 2002).

A similar inference may explain the Jurassic compsognathid fossil record. According to $\mathrm{Xu}$ (2006) and Chiappe and Göhlich (2010), complete skeletons of small theropods of this period are rare. Notably, Juravenator starki and Compsognathus longipes, the only two Jurassic compsognathid species, were respectively found in Schamhaupten and Solnhofen. Alternatively, one could suggest that these species represent the beginning of the compsognathid radiation, a hypothesis that the poor Jurassic theropod fossil record cannot rule out. However, some cladograms show $C$. longipes in a more derived position within Compsognathidae (Naish et al. 2004, Hwang et al. 2004, dal Sasso and Maganuco 2011), which could mean that the radiation had begun before the Late Jurassic times and not necessarily in Europe. Actually, this is an issue that requires further investigations based on new specimens.

Luo (1999) and, then, Zhou et al. (2003) suggested that Asia, especially the Chinese region, had acted as a refuge for many "tipically" Jurassic taxa due to the geographic isolation between that 
land mass and the rest of Laurasia during Middle Jurassic to Early Cretaceous. Among these taxa were the compsognathid Sinosauropteryx prima, considered the sister-group of $C$. longipes, and the anurognathid pterosaurs. However, the status of "typically Jurassic" assigned to Compsognathidae does not seem to be appropriate nowadays, as only two out of eight species are from Jurassic sedimentary deposits. Furthermore, Naish et al. (2004), based on the similarity of the pelvic girdle, considered Compsognathus longipes more similar to Mirischia asymmetrica than to $S$. prima. In fact, Manabe et al. (2000) suggested that the presence of 'Late Jurassic' taxa in Eastern Asia might be the result of a more gradual Jurassic-Cretaceous faunal transition.

Actually, once the paleobiogeographic distribution of compsognathids may have been biased by taphonomic factors, any analysis aiming to determine historical aspects and to identify dispersion events and/or vicariant evolution is not possible or secure enough to be performed. Moreover, if the distribution of these small theropods during Jurassic and Cretaceous was wider than that suggested by the fossil record, the presence of this taxon in Asia could be a consequence of a pangeic distribution. Accordingly, these animals might have arrived in Asia before the geographic isolation that began during the Jurassic as the result of the formation of the Turgai epicontinental sea (Upchurch et al. 2002), as proposed for spinosaurs (E. Buffetaut, unpublished data).

Paleobiogeography can be a tool to make paleoecological inferences, mainly when it is not possible to recognize anatomical adaptations to paleoecological conditions like the weather (Russell and Paesler 2003). However, keeping in mind the possibility of the compsognathid paleobiogeography being almost all restricted to Fossil Lagerstätten, any paleoecological generalization based on paleobiogeographic data does not seem to be very consistent for this taxon.
Another important fact is that, despite recognizing Sinosauropteryx prima, as the only Chinese species found until then, and Aristosuchus pusillus as members of Compsognathidae, Naish et al. (2004) did not mention these species in their inference about these theropods being exclusively adapted to inhabit semi-arid to arid environments. The Yixian Formation, where the three Chinese compsognathids were discovered, seems to have been deposited in an environmental setting that alternated between mesic and semi-arid conditions (Zhou et al. 2003). However, a warm and moist climate is also proposed for this stratigraphic unit, what fits better with the flourishing forest that presumably existed there, supporting many arboreal and herbivorous vertebrate taxa, including the gliding lizard Xianglong zhaoi and the arboreal theropod genus Microraptor (Xu et al. 2000, Zhou et al. 2003, Zhou 2006 and the references therein, Li et al. 2007). The presence of maculae in some cockroaches wings from this formation is also proposed to be related to a warm and moist climate (Tan and Ren 2006, Wang et al. 2007).

Plant taxa adapted to more mesic conditions also inhabited the Araripe Basin when the Crato Formation was deposited (Bernardes-de-Oliveira et al. 2007). Thus, mesic conditions should have been also present in some regions within the Crato Formation paleoenvironment (M.E.C. Bernardesde-Oliveira et al., unpublished data) and the same is plausible to Santana Formation, which overlies the former formation and shares with it many generic and supra-generic taxa. Furthermore, Frickhinger (1994) considered the absence of true ferns in the Solnhofen plattenkalk as an evidence of the absence of both abundant moisture and more or less shady habitats. However, these plants are found in Yixian and Crato Formations (Zhou et al. 2003, Martill et al. 2007, Bernardes-de-Oliveira et al. 2007). Therefore, the paleoenvironment of Yixian and, possibly, Santana Formation should have been relatively less arid than that of Solnhofen. 


\section{FINAL CONSIDERATIONS}

Although paleobiogeography may be useful for making paleoecological inferences by suggesting the main paleoecological factors present in the habitat during the lifespan of a taxon, including type of vegetation and climate (eg. Garcia 2007, Butler and Barrett 2008, Carvalho et al.2010), a geographic distribution pattern biased by taphonomic factors can limit considerably the possibility of this approach being applied. This seems to be the case of compsognathids, for which it is unsafe nowadays to perform any detailed paleobiogeographic analysis. Actually, this situation is aggravated by the fact that there is not an accurate phylogeny for this taxon as a whole, being not possible to recognize phylogenetic relationships among the eight species that could bring some insights for this question.

For this study's purposes it was possible at least to test and reject the proposition of Naish et al. (2004), which was not totally in accordance with the fossil record. Compsognathids also inhabited areas considerably moister than Solnhofen paleoenvironment, including forests. Finally the present work emphasizes the need of a critical analysis of the fossil record and its limitations before any further study.

\section{ACKNOWLEDGMENTS}

The authors are indebted to Felipe Pinheiro and Flávio Pretto for their contribution during the early stages of this work. They also want to thank three anonymous reviewers that provided helpful comments that improved this paper. Luis Chiappe, Karin Peyer and Shu' an Ji provided some references. This study was partly funded by Conselho Nacional de Desenvolvimento Científico e Tecnológico (CNPq), with a master fellowship to MAFS.

\section{RESUMO}

A paleogeografia do clado de terópodes Compsognathidae é aqui reavaliada a fim de testar a hipótese de este táxon ser exclusivamente adaptado a ambientes semiáridos. Os dados sobre as localidades onde esses fósseis foram coletados e seu paleoambiente foram levantados a partir da literatura. Compsognatídeos parecem ser encontrados especialmente em depósitos sedimentares conhecidos como Fossil Lagerstätten, os quais se formaram sob um conjunto de condições que possibilitaram a preservação dos frágeis elementos ósseos desses animais. Esse tendenciamento impede qualquer análise acurada da paleobiogeografia histórica ou ecológica deste táxon. Na realidade, é possível que compsognatídeos tenham tido uma distribuição por quase todo o planeta durante a Era Mesozoica. Sua ocorrência nas rochas do Cretáceo Inferior na China sugere que também ocupavam ambientes com condições húmidas em vez de estarem restritos a ambientes semiáridos e áridos.

Palavras-chave: Compsognathidae, Fossil Lagerstätten, registro fóssil, paleobiogeografia, paleoecologia, Theropoda.

\section{REFERENCES}

Antunes MT And Mateus O. 2003. Dinosaurs of Portugal. C R Palevol 2: 77-95.

Benton MJ. 2010. Studying Function and Behavior in the Fossil Record. PLoS Biol 8: 1-5.

Bernardes-De-Oliveira MEC, MOHR B, Dino R, GUERRASOMMER M, GARCIA MJ AND SUCERQUIA PA. 2007. As floras mesofíticas brasileiras no cenário paleoflorístico mundial. In: CARVALHO IS ET AL. (Eds), Paleontologia: Cenários de Vida, Vol. 1, Rio de Janeiro: Editora Interciência, p. 195-233.

BITTENCOURT JS AND LANGER MC. 2011. Mesozoic dinosaurs from Brazil and their biogeographic implications. An Acad Bras Cienc 83: 23-60.

Blakey R. 2006. Mollewide Plate Tectonic Maps. NAU Geology. <http://www2.nau.edu/rcb7/globaltext2.html >

BUTLER RJ AND BARRETT PM. 2008. Palaeoenvironmental controls on the distribution of Cretaceous herbivorous dinosaurs. Naturwissenschaften 95: 1027-1032.

BUTLER RJ AND UPCHURCH P. 2007. Highly incomplete taxa and the phyllogenetic relationships of the theropod dinosaur Juravenator starki. J Vertebr Paleontol 27 253-256.

CARVAlHo IS, Gasparini ZB, SALgado L, VASCONCELlos FM AND MARINHO TS. 2010. Climate's role in the distribution of the Cretaceous terrestrial Crocodyliformes throughout Gondwana. Palaeogeogr Palaeoclimatol Palaeoecol 297: 252-262. 
CHEN PJ, Dong ZM And ZHEN SN. 1998. An exceptionally well-preserved theropod dinosaur from the Yixian Formation of China. Nature 391: 147-152.

CHIAPPE LM AND GÖHLICH UB. 2010. Anatomy of Juravenator starki (Theropoda: Coelurosauria) from the Late Jurassic of Germany. N Jahrb Geol Paläontol A 258: 257-296.

DAL SASSO C. 2003. Dinosaurs of Italy. C R Palevol 2: 45-66.

DAL SASSO C AND MAGANUCO S. 2011. Scipionyx samniticus (Theropoda: Compsognathidae) from the Lower Cretaceous of Italy - Osteology, ontogenetic assessment, phylogeny, soft tissue anatomy, taphonomy and palaeobiology. Memorie della Società Italiana di Scienze Naturali e del Museo Civico di Storia Naturale di Milano 37: 1-281.

DAL SASSo C AND SignORE M. 1998. Exceptional soft-tissue preservation in a theropod dinosaur from Italy. Nature 392: 383-387.

FRICKHINGER KA. 1994. The Fossils of Solnhofen. Goldschneck-Verlag, 336 p.

GARCIA KL. 2007. A Família Peirosauridae do Cretáceo do Gondwana: Taxonomia comparada e implicações paleogeográficas. In: CARVALHO IS ET AL. (Eds), Paleontologia: Cenários de Vida, Vol. 1, Rio de Janeiro: Editora Interciência, p. 393-404.

GÖHLICH UB AND CHIAPPE LM. 2006. A new carnivorous dinosaur from the Late Jurassic Solnhofen archipelago. Nature 440: 329-332.

HOLTZ JR TR. 1998. A new phylogeny of the carnivorous dinosaurs. Gaia 15: 5-61.

Hwang SH, Norrell MA, Ji Q AND GAO K. 2004. A large Compsognathid from the Early Cretaceous Yixian formation of China. J Syst Palaeontol 2: 13-30.

Ji S, Ji Q, LÜ J AND YuXIAN C. 2007. A New Giant Compsognathidae with Long Filamentous Integuments from Lower Cretaceous of Northeastern China. Acta Geol Sinica 81: 8-15.

LeOnardi G, CARvalho IS And Fernandes MA. 2007. The desert ichnofauna from Botucatu Formation (Upper Jurassic - Lower Cretaceous), Brazil. In: CARVALHO IS ET AL. (Eds), Paleontologia: Cenários de Vida, Vol. 1, Rio de Janeiro: Editora Interciência, p. 371-383.

Li P, GAO K, Hou L AND XU X. 2007. A gliding lizard from the Early Cretaceous of China. PNAS 104: 5507-5509.

LiU Y, Kuang H, Jiang X, Peng N, Xu H and Sun H. 2012. Timing of the earliest known feathered dinosaurs and transitional pterosaurs older than the Jehol Biota. Palaeo 323/325: 1-12.

LUCAS SG. 2001. Chinese Fossil Vertebrates, New York: Columbia University Press, 375 p.

LuO Z. 1999. A refugium for relicts. Nature 400: 23-25.

MAISEY JG. 1991. Santana Fossils - An Illustrated Atlas, Neptune City: Tropical Fish Hobbyist Publications, 459 p.

MANABE M, BARRETT PM AND ISAJI S. 2000. A refugium for relicts? Nature 404: 953.

MARTILL DM. 1990. The Significance of the Santana Biota. In: SIMPÓSIO SOBRE A BACIA DO ARARIPE E BACIAS INTERIORES DO NORDESTE, I, Crato, Atas, Crato, URCA, p. 241-252.
Martill DM, Bechly G AND LOVERIDGE RF (EDS). 2007. The Crato Fossil Beds of Brazil - Window into an Ancient World, New York: Cambridge University Press, 625 p.

Mateus O, Walen A And Antunes MT. 2006. The large theropod fauna of the Lourinhã Formation (Portugal) and its similarity to the Morrison Formation, with a description of a new species of Allosaurus. Bull NMMNH 36: 223-231.

NAISH D. 2002. The historical taxonomy of the Lower Cretaceous theropods (Dinosauria) Calamospondylus and Aristosuchus from the Isle of Wight. Proc Geol Assoc 113: 153-163.

NAISH D AND MARTILL DM. 2007. Dinosaurs of Great Britain and the role of the Geological Society of London in their discovery: basal Dinosauria and Saurischia. J Geol Soc 164: 493-510.

NAish D, MARTILl DM AND Frey E. 2004. Ecology, Systematics and Biogeographical Relationships of Dinosaurs, Including a New Theropod, from the Santana Formation (?Albian, Early Cretaceous) of Brazil. Hist Biol 1-14.

NORMAN DB. 1990. Problematic theropoda: coelurosaurs. In: WEISHAMPEL DB ET AL. (Eds), The Dinosauria, Berkeley: University of California Press, p. 280-305.

OSTROM JH. 1978. The osteology of Compsognathus longipes Wagner. Zitteliana 4: 73-118.

PEYER K. 2006. A reconsideration of Compsognathus from the Upper Tithonian of Canjuers, southeastern France. J Vertebr Paleont 26: 879-896.

RUSSELl DA AND PAESLER MA. 2003. Environments of MidCretaceous Saharan dinosaurs. Cretaceous Res 24: 569-588.

SCOTESE CR. 2002. PALEOMAP Project. <http://www. scotese.com>

SEELEY HG. 1887. On Aristosuchus pusillus (Owen), being Further Notes on the Fossils described by Sir R. Owen as Poikilopleuron pusillus, Owen. Q J Geol Soc 43: 221-228.

SENTER P. 2007. A new look at the Phylogeny of Coelurosauria (Dinosauria: Theropoda). J Syst Palaeontol 5: 429-463.

SERENO PC. 1999. The Evolution of Dinosaurs. Science 284: 2137-2147.

SERENO PC, WILSON JA AND CONRAD JL. 2004. New dinosaurs link southern landmasses in the Mid-Cretaceous. Proc R Soc London B 271: 1325-1330.

TAN J AND REN D. 2006. New fossil Piacrimini (Insecta: Coleoptera: Archostemata: Cupedidae) from the Jehol Biota of China. J Nat Hist 40: 2653-2661.

UPCHURCH P, HUNN CA AND NORMAN DB. 2002. An analysis of dinosaurian biogeography: evidence for the existence of vicariance and dispersal patterns caused by geological events. Proc R Soc London B 269: 613-621.

WANG T, Dong R, Liang JH AND SHIH C. 2007. New Mesozoic cockroaches (Blattaria: Blattulidae) from Jehol Biota of Western Liaoning in China. Annales Zoologici 57: 483-495.

XU X. 2006. Scales, feathers and dinosaurs. Nature 440: $287-$ 288. 
XU X, ZHOU Z AND WANG X. 2000. The smallest non-avian theropod dinosaur. Nature 408: 705-708.

ZhANG F, KEARNS SL, ORR PJ, BENTON MJ, ZHOU Z, JOHNSON D, XU X AND WANG X. 2010. Fossilized melanosomes and the colour of Cretaceous dinosaurs and birds. Nature 463: 1075-1078.

ZhANG F, ZHOU Z AND DYKe G. 2006. Feathers and 'featherlike' integumentary structures in Liaoning birds and dinosaurs. Geol J 41: 395-404.
ZHOU Z. 2006. Evolutionary radiation of the Jehol Biota: chronological and ecological perspectives. Geol J 41: 377-393.

ZhOU Z, BARRETT PM AND Hilton J. 2003. An exceptionally preserved Lower Cretaceous ecosystem. Nature 421: 807814. 